\title{
Evaluation of the effect of denture adhesives on surface roughness of two chemically different denture base resins
}

\author{
Mahmoud Darwish ${ }^{1,2}$, Mohammad Zakaria Nassani $^{1,3}$
}

Correspondence: Dr. Mohammad Zakaria Nassani

Email: mznassani@hotmail.com

\begin{abstract}
'Department of Prosthetic Dental Sciences, Al-Farabi Colleges, Riyadh, Saudi Arabia,

${ }^{2}$ Department of Prosthodontics, Faculty of Dentistry, Suez Canal University, Ismailia, Egypt,

${ }^{3}$ Department of Removable Prosthodontics, Faculty of Dentistry, University of Aleppo, Aleppo, Syria
\end{abstract}

\section{ABSTRACT}

Objective: To evaluate the effect of four commercially available denture adhesives (DAs) on surface roughness of two chemically different denture base materials. Materials and Methods: Fifty specimens of heat-cured polymethyl methacrylate, and another fifty specimens of light-cured urethane dimethacrylate were divided into five groups $(n=10)$, each was immersed in four prepared DAs (Corega Super Cream, Corega Ultra Powder, Olivafix Cream, Protefix Cream) as well as distilled water (control group). The mean surface roughness $\left(R_{\mathrm{a}}\right)$ of the polished and unpolished surfaces of the specimens was recorded using profilometer device. $T$-test for paired observation was used to indicate any changes in surface roughness between the baseline and after 30 days of immersion in the DA. Results: Almost all the tested DAs had no significant effect on the roughness of polished and unpolished surfaces of both denture base materials. The Corega super cream DA produced significant increase in the roughness of the polished surfaces of both types of acrylic specimens $(P<0.05)$. Conclusion: The majority of the investigated DAs appears not to affect the surface roughness of denture base materials. Only Corega super cream DA produced detectable increase in the roughness of polished surfaces of denture base specimens.

Key words: Denture adhesives, denture base materials, surface roughness

\section{INTRODUCTION}

Commercial denture adhesives (DAs) are substances intended to improve the relationship between the denture base and underlying tissue. Some studies show that about $15-33 \%$ of the edentulous patients with complete removable prosthesis use complementary adhesive systems. ${ }^{[1,2]}$ In spite of great advantages of using DAs for complete denture wearers, the earlier literature mentions unfavorable characteristics such as vertical dimension increase, mucosa hypersensitivity reactions, and altered oral flora. ${ }^{[2-4]}$

\begin{tabular}{|l|l|}
\hline \multicolumn{2}{|c|}{ Access this article online } \\
\hline Quick Response Code: \\
\hline
\end{tabular}

During use, the denture base materials have to retain their mechanical and physical properties, as well as surface smoothness and integrity, be impermeable to oral fluids and resist the bacterial action and growth. ${ }^{[5]}$

Surface roughness and degradation of the acrylic dentures contribute to the adherence, bonding, and colonization of microorganisms. ${ }^{[6-8]}$ The consequences may be an increase in the prevalence of denture-related stomatitis,

This is an open access article distributed under the terms of the Creative Commons Attribution-NonCommercial-ShareAlike 3.0 License, which allows others to remix, tweak, and build upon the work non-commercially, as long as the author is credited and the new creations are licensed under the identical terms.

For reprints contact: reprints@medknow.com

How to cite this article: Darwish M, Nassani MZ. Evaluation of the effect of denture adhesives on surface roughness of two chemically different denture base resins. Eur J Dent 2016;10:321-6.

DOI: $10.4103 / 1305-7456.184155$ 
rate of staining, halitosis, as well as psychological discomfort, nausea, and social problems. ${ }^{[9-12]}$

In addition to the toxic effect of the leach out components of acrylic resin degradation, premature failure of acrylic denture base is highly expected as a consequence of the changes in physical and mechanical properties. ${ }^{[13]}$

The literature is lacking information about the influence of the DA on the surface integrity of denture base materials. This is despite the common use of DA among the edentulous patients. The aim of this study was to evaluate the effect of DAs on the surface roughness of two chemically different denture base resins; heat-cured polymethyl methacrylate (PMMA) resin and light-cured urethane dimethacrylate (UDMA) resin. The hypothesis to be tested is that the application of DA will have no impact on the surface roughness of both types of denture base resins.

\section{MATERIALS AND METHODS}

The types, chemical composition, and manufacturers of the DAs and denture base materials used in this study are listed in Table 1.

\section{Sample fabrication}

One hundred square samples of two types of denture base resins measuring $(10 \mathrm{~mm} \times 10 \mathrm{~mm} \times 2 \mathrm{~mm})$ were prepared. Fifty samples for PMMA resin and 50 samples for UDMA resin.

PMMA specimens were prepared by investing pieces of modeling wax (Cavex-Holand BV) in stone plaster (LabStone-Dentsply) by a conventional flasking procedure in metallic dental flask according to the manufacturer's instructions.

For UDMA (Eclipse) specimens, a silicon mold was created by investing wax into silicon material (Degoform plus-DeguDent GmbH, Germany). The silicon mold was lined with a separating agent (Al-Cote-Dentsply, USA) and warmed in the conditioning oven. Afterward, the prepacked resin was adapted into the silicon mold using finger pressure. The exposed surface of UDMA specimen was lined with air barrier coating (Eclipse, Air Barrier Coating, Dentsply, USA) and polymerization was carried out in a curing unit (Eclipse, Dentsply, USA) for $10 \mathrm{~min}$.

All the specimens were visually inspected and checked for the absence of voids or porosity. Defected samples were discarded. The study specimens were prepared to the required dimensions by finishing discs and stones using a handpiece at low speed. Both surfaces were finished using 280, 360, and 400 grit abrasive papers (Middle East Factory - K.S.A, Riyadh, Saudi Arabia). One surface of each specimen was polished on wet rag wheel with slurry pumice and the other surface was left unpolished.

All the test specimens were stored in distilled water at $37^{\circ} \mathrm{C}$ for $48 \mathrm{~h}$ for residual monomer elimination. After that, all the specimens were dried with air and numbered and the initial surface roughness was measured for both sides of each specimen. Then, the specimens of both groups were randomly divided into five subgroups $(n=10)$. Four test groups for immersion in four different DA and one control group for immersion in distilled water.

\begin{tabular}{|c|c|c|c|c|}
\hline Product name & Material type & Composition & Manufacturer & Batch number \\
\hline $\begin{array}{l}\text { Corega super } \\
\text { cream }\end{array}$ & Denture adhesive & $\begin{array}{l}\text { Poly (methylvinylether/maleic acid) } \\
\text { sodium-calcium mixed partial salt, petrolatum, } \\
\text { cellulose gum, paraffinum liquidum }\end{array}$ & $\begin{array}{l}\text { Stafford-Miller } \\
\text { (Dungarvan, Irland) }\end{array}$ & V12353A \\
\hline $\begin{array}{l}\text { Corega ultra } \\
\text { powder }\end{array}$ & Denture adhesive & $\begin{array}{l}\text { Poly (methylvinylether/maleic acid) sodium-calcium } \\
\text { mixed partial salt, cellulose gum, flavor }\end{array}$ & $\begin{array}{l}\text { Stafford-Miller } \\
\text { (Dungarvan, Irland) }\end{array}$ & N13032 \\
\hline Olivafix cream & Denture adhesive & $\begin{array}{l}\text { Cellulose gum, Olea Europea (olive oil), calcium/ } \\
\text { sodium, PVM/MA copolymer, hydrogenated } \\
\text { soybean oil, trihydroxystearin, silica, mentol, } \\
\text { lecithin, citrus limonum, menthyl lactate }\end{array}$ & $\begin{array}{l}\text { Bonyf AG- } \\
\text { (Liechtenstein. } \\
\text { EU) - Swiss }\end{array}$ & $41-27$ \\
\hline Protefix cream & Denture adhesive & $\begin{array}{l}\text { Poly (methylvinylether/maleic acid) sodium/calcium partial } \\
\text { salt, carboxymethyl cellulose, paraffin, vaseline, silica, } \\
\text { menthol, azorubin, p-hydroxy-benzoic acid methyl ester }\end{array}$ & $\begin{array}{l}\text { Queisser Pharma } \\
\text { (Flensburg, Germany) }\end{array}$ & 088072 \\
\hline Eclipse & Denture base resin & $\begin{array}{l}\text { Matrix: UDMA } \\
\text { Filler: Silica, PMMA beads }\end{array}$ & $\begin{array}{l}\text { Dentsply, New York, } \\
\text { USA }\end{array}$ & 120612 \\
\hline Ecocryl-Hot & Denture base resin & $\begin{array}{l}\text { Powder: Methylmethacrylate-copolymer } \\
\text { Liquid: Methylmethacrylate-monomer }\end{array}$ & $\begin{array}{l}\text { Protechno, Girona, } \\
\text { Spain }\end{array}$ & $12-26964$ \\
\hline
\end{tabular}




\section{Denture adhesives preparation}

One gram of the four used DAs [Table 1] was weighed and mixed with $10 \mathrm{ml}$ distilled water in a plastic container. After dilution with water, the $\mathrm{pH}$ values of each DA were measured using $\mathrm{pH}$ meter (HANNA pH211-Woonsocket RI USA). Table 2 shows the measured $\mathrm{pH}$ values for the used DAs.

Four test groups of PMMA and UDMA specimens were completely immersed in the four prepared DAs, and the fifth group of specimens was immersed in a plastic container with $10 \mathrm{ml}$ distilled water.

The immersion time was $16 \mathrm{~h} /$ day. The containers were covered and stored in an incubator at $37^{\circ} \mathrm{C}$. Next, the specimens were removed out of the prepared DA and rinsed under running water. After that, each group of samples was stored in distilled water for $8 \mathrm{~h}$ at room temperature. The DA was replaced and prepared daily and the procedure was repeated for 30 days.

\section{Measuring the surface roughness $\left(R_{\mathrm{a}}\right)$}

The $R_{\mathrm{a}}$ values were measured using a contact profilometer device (MarSurf PS1-MahrGmbH. GÖttingen-Germany). The instrument complied with DIN EN ISO 3274 standards. The profilometer can measure small surface variations by moving a diamond stylus across the specimen surface [Figure 1]. The tracing length of the instrument stylus was $5.6 \mathrm{~mm}$ and a cut-off of $0.8 \mathrm{~mm}$ at speed of $0.5 \mathrm{~mm} / \mathrm{s}$. The $R_{\mathrm{a}}$ value is the arithmetic average assigned to peaks and valleys of an area provided in $\mu \mathrm{m}$.

The baseline $R_{\mathrm{a}}$ measurements were taken for both sides of each sample of the five study groups before immersion in the adhesives. The stylus moved across the specimen surface and three lines were recorded with a distance of $1 \mathrm{~mm}$ between each scanning line. The mean value for the three readings of the $R_{\mathrm{a}}$ was considered the surface roughness value for each specimen surface.

After 30 days of immersion, the specimens were removed, washed with running water for $10 \mathrm{~s}$, and dried with compressed air. The final $R_{\mathrm{a}}$ of each test

\begin{tabular}{lc} 
Table 2: $\mathbf{p H}$ values of the denture adhesives \\
\hline Denture adhesive & $\mathrm{pH}$ values (at 22.5 ${ }^{\circ} \mathrm{C}$ ) \\
\hline Corega super cream & 5.52 \\
Corega powder & 6.74 \\
Olive fix cream & 7.31 \\
Protefix cream & 6.13 \\
\hline
\end{tabular}

specimen was measured again as before immersion for both sides. The mean $R_{\mathrm{a}}$ was calculated and tabulated in a special form.

\section{Statistical analysis}

The collected data were analyzed using the SPSS statistical package (IBM SPSS Statistics for Windows, Version 20.0, Released 2011, IBM Corp., Armonk, New York, USA).

The mean and standard deviation of $R_{\mathrm{a}}$ for the study groups were calculated using descriptive data analysis.

$T$-test for paired observation was used to indicate any changes in $R_{\mathrm{a}}$ between the baseline and after 30 days of immersion in the DA.

\section{RESULTS}

Mean values and standard deviations of $R_{\mathrm{a}}$ for the PMMA and UDMA specimens at baseline and after 30 days of immersion in the DA are shown in Tables 3-6.

The $t$-test for paired observation indicated significant change in the roughness of the PMMA polished surfaces for the specimens that were immersed in the Corega cream adhesive $(P<0.05)$. No significant changes in surface roughness were noted with the other used DA [Table 3]. The same statistical test revealed that DA had no impact on surface roughness of the unpolished surfaces of the PMMA specimens [Table 5].

Similar results were observed with the UDMA specimens as DA had no impact on roughness of the polished and unpolished surfaces of the

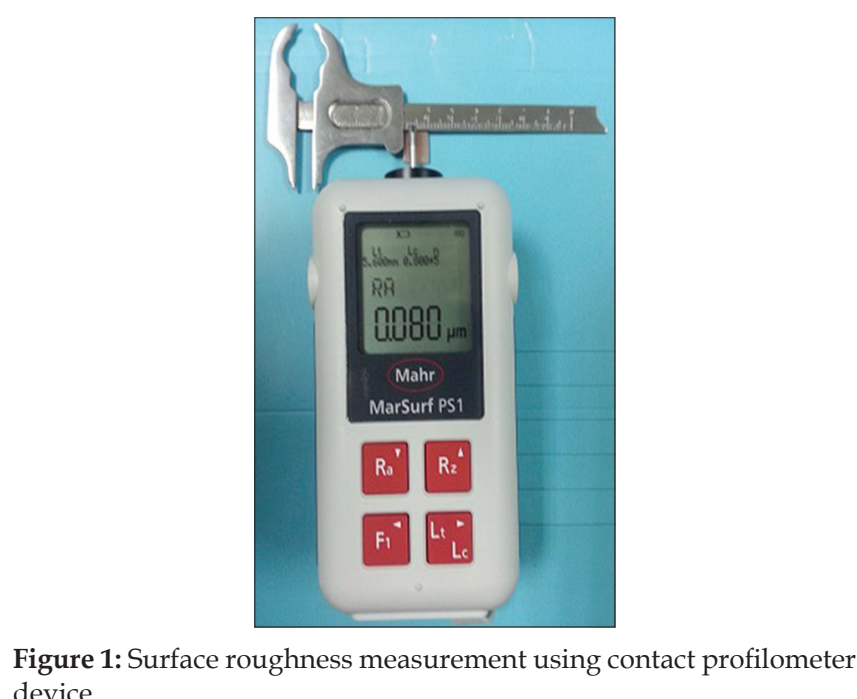
device 


\begin{tabular}{|c|c|c|c|c|}
\hline \multirow{2}{*}{$\begin{array}{l}\text { Study } \\
\text { groups }\end{array}$} & \multicolumn{4}{|c|}{ Polished surface/PMMA } \\
\hline & $\begin{array}{c}\text { Initial } R_{\mathrm{a}} \\
\text { value }(\mu \mathrm{m})\end{array}$ & $\begin{array}{c}\text { Final } R_{\mathrm{a}} \\
\text { value }(\mu \mathrm{m})\end{array}$ & $\begin{array}{c}\Delta R_{\mathrm{a}} \\
\text { values }(\mu \mathrm{m})\end{array}$ & $P$ \\
\hline $\begin{array}{l}\text { Corega cream } \\
\text { group }\end{array}$ & $0.129(0.028)$ & $0.139(0.022)$ & $0.01(0.011)$ & $0.023^{*}$ \\
\hline $\begin{array}{l}\text { Corega powder } \\
\text { group }\end{array}$ & $0.109(0.014)$ & $0.117(0.021)$ & $0.008(0.013)$ & 0.079 \\
\hline $\begin{array}{l}\text { Olivafix cream } \\
\text { group }\end{array}$ & $0.172(0.046)$ & $0.174(0.042)$ & $0.002(0.055)$ & 0.916 \\
\hline $\begin{array}{l}\text { Protefix cream } \\
\text { group }\end{array}$ & $0.096(0.018)$ & $0.103(0.018)$ & $0.007(0.016)$ & 0.178 \\
\hline $\begin{array}{l}\text { Distilled water } \\
\text { (control group) }\end{array}$ & $0.143(0.025)$ & $0.145(0.024)$ & $0.002(0.004)$ & 0.102 \\
\hline
\end{tabular}

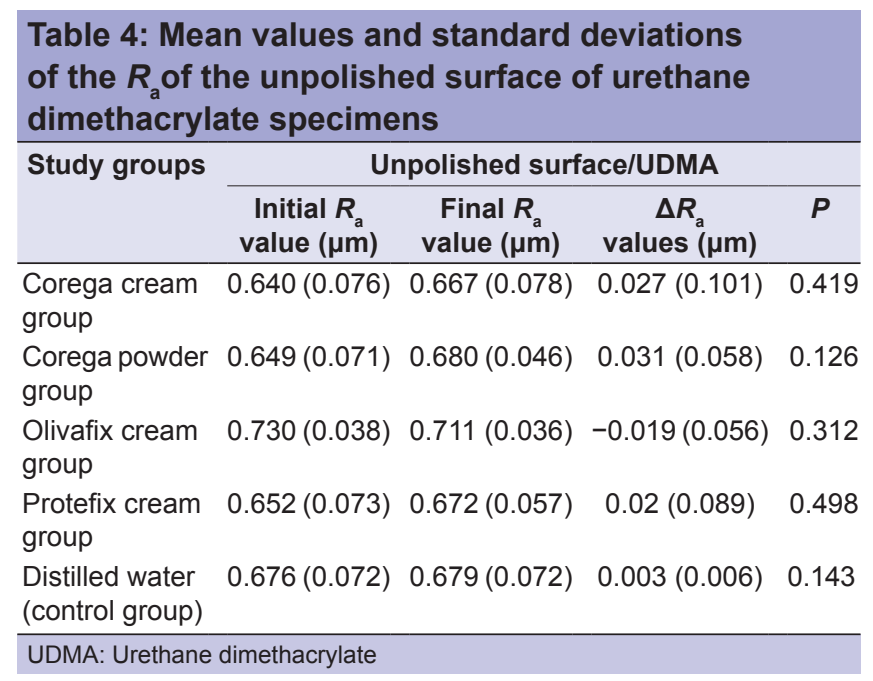

specimens except for the polished surfaces of the specimens that were immersed in Corega cream adhesive [Tables 4 and 6].

\section{DISCUSSION}

Most of the characteristics of DA was thoroughly evaluated by the previous investigations, regarding cytotoxic effect, reduction of the mucosal irritation beneath the denture, enhancement of the denture retention, bite force, chewing efficiency, and patient comfort as well as improvement in the oral health-related quality of life. ${ }^{[14]}$ However, the extent to which DA may affect denture surface integrity in term of change in surface roughness is not yet clear. This study can be considered the first attempt to clarify the effect of four commercially available DAs on the surface roughness of two chemically different denture base materials. The heat-cured PMMA is conventional

\begin{tabular}{|c|c|c|c|c|}
\hline \multirow[t]{2}{*}{ Study groups } & \multicolumn{4}{|c|}{ Unpolished surface/PMMA } \\
\hline & $\begin{array}{c}\text { Initial } R_{\mathrm{a}} \\
\text { value }(\mu \mathrm{m})\end{array}$ & $\begin{array}{c}\text { Final } R_{\mathrm{a}} \\
\text { value }(\mu \mathrm{m})\end{array}$ & $\begin{array}{c}\Delta R_{\mathrm{a}} \\
\text { values }(\mu \mathrm{m})\end{array}$ & $\boldsymbol{P}$ \\
\hline $\begin{array}{l}\text { Corega cream } \\
\text { group }\end{array}$ & $0.952(0.143)$ & $0.983(0.140)$ & $0.031(0.142)$ & 0.517 \\
\hline $\begin{array}{l}\text { Corega powder } \\
\text { group }\end{array}$ & $0.754(0.060)$ & $0.726(0.100)$ & $-0.028(0.115)$ & 0.466 \\
\hline $\begin{array}{l}\text { Olivafix cream } \\
\text { group }\end{array}$ & $0.967(0.455)$ & $0.958(0.428)$ & $-0.009(0.698)$ & 0.968 \\
\hline $\begin{array}{l}\text { Protefix cream } \\
\text { group }\end{array}$ & $0.858(0.101)$ & $0.888(0.109)$ & $0.03(0.084)$ & 0.286 \\
\hline $\begin{array}{l}\text { Distilled water } \\
\text { (control group) }\end{array}$ & $0.901(0.259)$ & $0.916(0.262)$ & $0.015(0.023)$ & 0.061 \\
\hline
\end{tabular}

\begin{tabular}{|c|c|c|c|c|}
\hline \multirow{2}{*}{$\begin{array}{l}\text { Study } \\
\text { groups }\end{array}$} & \multicolumn{4}{|c|}{ Polished surface/UDMA } \\
\hline & $\begin{array}{c}\text { Initial } R_{\mathrm{a}} \\
\text { value }(\mu \mathrm{m})\end{array}$ & $\begin{array}{c}\text { Final } R_{\mathrm{a}} \\
\text { value }(\mu \mathrm{m})\end{array}$ & $\begin{array}{c}\Delta R_{\mathrm{a}} \\
\text { values }(\mu \mathrm{m})\end{array}$ & $P$ \\
\hline $\begin{array}{l}\text { Corega cream } \\
\text { group }\end{array}$ & $0.129(0.015)$ & $0.172(0.042)$ & $0.043(0.037)$ & $0.006^{*}$ \\
\hline $\begin{array}{l}\text { Corega powder } \\
\text { group }\end{array}$ & $0.161(0.024)$ & $0.157(0.024)$ & $-0.004(0.027)$ & 0.625 \\
\hline $\begin{array}{l}\text { Olivafix cream } \\
\text { group }\end{array}$ & $0.140(0.022)$ & $0.143(0.022)$ & $0.003(0.035)$ & 0.835 \\
\hline $\begin{array}{l}\text { Protefix cream } \\
\text { group }\end{array}$ & $0.149(0.034)$ & $0.155(0.038)$ & $0.006(0.011)$ & 0.118 \\
\hline $\begin{array}{l}\text { Distilled water } \\
\text { (control group) }\end{array}$ & $0.147(0.019)$ & $0.145(0.018)$ & $-0.002(0.012)$ & 0.705 \\
\hline
\end{tabular}

and most commonly used denture base material and the light-cured UDMA denture resin may be used in patient's allergic to MMA monomer. ${ }^{[15,16]}$

Surface roughness of denture base materials is considered one of the determinant factors in the clinical longevity of the dental prosthesis. ${ }^{[17,18]}$

Ideally, a surface with the lowest possible roughness is recommended to hinder microorganism retention, prevent local infections and early denture deterioration. ${ }^{[19]}$

In 1997, a clinical study by Bollen et al. ${ }^{[20]}$ established that the threshold $R_{\mathrm{a}}$ for plaque retention of intraoral materials was $0.2 \mu \mathrm{m}$. Below this value, no further reduction in plaque accumulation can be expected. Above this value, a proportional increase in plaque accumulation may occur. ${ }^{[21]}$ 
In the present study, the changes in surface roughness of the acrylic resin specimens were measured by using a profilometer device as similar to previous investigations. ${ }^{[7,22,23]}$ The main advantage of this method is that it is easy to conduct; accurate and the mean surface roughness of the acrylic specimens can be easily calculated. $R_{\mathrm{a}}$ is the arithmetic average height measurement, being frequently used as a universal roughness parameter for general quality control. ${ }^{[24]}$

The DAs tested in this study were dissolved in distilled water at percent solution consistent with expected conditions in the oral cavity as recommended by earlier studies. ${ }^{[3,25]}$

Overall, the findings of this study partially support the hypothesis of no change in surface roughness following the application of DA.

The Corega cream was the only DA that affected the roughness of the polished surface for both types of denture base materials. This finding may be related to the low $\mathrm{pH}$ value of the Corega cream $(\mathrm{pH}=5.52)$ compared with other tested DAs as presented in Table 2. Under acidic conditions, the polymer surface may be softened by loss of structural ions. ${ }^{[24]}$ Koda et al. ${ }^{[26]}$ found that at lower $\mathrm{pH}$ conditions, there was an increase in the concentration of MMA monomer leached from the denture base acrylic resin. In addition, Jaeggi et al..$^{[27]}$ stated that under acidic condition, restorative materials including composite resin may suffer degradation which can be predicted by change in the surface topography and roughness.

In a study by Constantinescu et al. ${ }^{[18]}$ the denture base acrylic resins showed higher roughness when the $\mathrm{pH}$ was more acid. The authors related the changes in surface features and the increased surface roughness to factors leading to salivary acidity. Love and Biswas ${ }^{[3]}$ recommended that DA with low $\mathrm{pH}$ values should not be used in an environment with natural teeth or remnants of natural teeth because the prolonged contact of DA with tooth substance may dissolve hydroxyapatite crystals.

The low $\mathrm{pH}$ can also change the UDMA resin matrix by acting as a catalyst for the ester groups that are present in dimethacrylate monomers. This process may cause degradation of the polymer network and lead to a phenomenon known as plasticization that may change the surface properties of the resin. ${ }^{[28,29]}$

Increase of the surface roughness of the Corega cream group may also be related to the presence of paraffinum liquidum. Among the studied DAs, the Corega cream is the only DA that contains the paraffinum liquidum in its composition. This mineral oil is added to the water-soluble polymer powder to give it the paste form. The liquid paraffin may have a plasticizing effect causing plasticization of polymer chains, leading to material degradation by increased water sorption and solubility. ${ }^{[30]}$

While the Corega cream affected the roughness of the polished surface of the used denture base materials, there was no apparent effect for this DA on the roughness of the unpolished surface. The relatively short exposure time to the DA may play a role in this finding. Another possible explanation may be due to the difficulty of complete removal of DA from rough surfaces of the samples by the used protocol of cleaning. This opinion may be supported by the clinical study done by Uysal et al., who reported that $20-30 \%$ of the patients found it difficult or extremely difficult to remove the adhesive from the denture base and oral tissues. ${ }^{[31]}$ The valleys of the rough surface may be clogged by the adhesive remnants after drying with air. Clogging of the valleys may affect $R_{\mathrm{a}}$ value, resulting in nonsignificant effect, as it is known that $R_{\mathrm{a}}$ value is the arithmetic average assigned to peaks and valleys of an area.

The effect of other tested DAs on the surface roughness of both types of denture base materials was nonstatistically significant which is a desirable property for any DA not to alter or degrade the surface of the denture base material on which it is applied. ${ }^{[25,32]}$ This finding may be the outcome of compatibility in the chemical composition between the used acrylic denture base materials and the DA as well as the suitability of its $\mathrm{pH}$ values.

The limitation of this in vitro study is that the DA was used in one concentration, which does not occur clinically because of the continuous dilution by saliva during denture wearing. However, this concentration could represent longer application time. In addition, the study is limited in simulating the intraoral condition of temperature and $\mathrm{pH}$ fluctuations combined with the mechanical loading during masticatory function. Further, the denture base surfaces used in the present study do not adequately represent the intaglio surface features of a denture in vivo. In this respect, the effect of DA on surface roughness of denture base materials under in vivo conditions may differ from this in vitro study. Additional clinical studies are also necessary to clarify the long term effect of different DA on the surface properties of denture base materials. 


\section{CONCLUSION}

Within the limitations of this study, the majority of the investigated DAs appears not to affect the surface roughness of denture base materials.

Only Corega super cream DA produced detectable increase in the roughness of the polished surface of denture base specimens.

\section{Acknowledgments}

We sincerely thank Dr. Ahmed Al-Mutairi (BDS, SDT, College of Dentistry, King Saud University) for his assistance in making the Eclipse specimens.

\section{Financial support and sponsorship Nil.}

\section{Conflicts of interest}

There are no conflicts of interest.

\section{REFERENCES}

1. Coates AJ. Usage of denture adhesives. J Dent 2000;28:137-40.

2. Stafford GD, Russell C. Efficiency of denture adhesives and their possible influence on oral microorganisms. J Dent Res 1971;50:832-6.

3. Love WB, Biswas S. Denture adhesives - PH and buffering capacity. J Prosthet Dent 1991;66:356-60.

4. Benson D, Rothman RS, Sims TN. The effect of a denture adhesive on the oral mucosa and vertical dimension of complete denture patients. J South Calif Dent Assoc 1972;40:468-73.

5. Rahal JS, Mesquita MF, Henriques GE, Nóbilo MA. Influence of chemical and mechanical polishing on water sorption and solubility of denture base acrylic resins. Braz Dent J 2004;15:225-30.

6. Combe EC, Owen BA, Hodges JS. A protocol for determining the surface free energy of dental materials. Dent Mater 2004;20:262-8

7. Sczepanski F, Sczepanski CR, Berger SB, Consani RL, Gonini-Júnior A, Guiraldo RD. Effect of sodium hypochlorite and peracetic acid on the surface roughness of acrylic resin polymerized by heated water for short and long cycles. Eur J Dent 2014;8:533-7.

8. da Silva WJ, Rached RN, Rosalen PL, Del bel Cury AA. Effects of nystatin, fluconazole and propolis on poly(methyl methacrylate) resin surface. Braz Dent J 2008;19:190-6.

9. Taylor R, Maryan C, Verran J. Retention of oral microorganisms on cobalt-chromium alloy and dental acrylic resin with different surface finishes. J Prosthet Dent 1998;80:592-7.

10. Murray ID, McCabe JF, Storer R. Abrasivity of denture cleaning pastes in vitro and in situ. Br Dent J 1986;161:137-41.

11. Whitehead KA, Verran J. The effect of surface topography on the retention of microorganisms. Food Bioproducts Process 2006;84:253-9.

12. Allis TJ, Leopold DA. Smell and taste disorders. Facial Plast Surg Clin North Am 2012;20:93-111.

13. Bettencourt AF, Neves CB, de Almeida MS, Pinheiro LM, Oliveira SA Lopes LP, et al. Biodegradation of acrylic based resins: A review. Dent Mater 2010;26:e171-80.

14. Duqum I, Powers KA, Cooper L, Felton D. Denture adhesive use in complete dentures: Clinical recommendations and review of the literature. Gen Dent 2012;60:467-77.

15. Machado C, Sanchez E, Azer SS, Uribe JM. Comparative study of the transverse strength of three denture base materials. J Dent 2007;35:930-3.

16. Rashid H, Sheikh Z, Vohra F. Allergic effects of the residual monomer used in denture base acrylic resins. Eur J Dent 2015;9:614-9.

17. Willershausen B, Callaway A, Ernst CP, Stender E. The influence of oral bacteria on the surfaces of resin-based dental restorative materials - An in vitro study. Int Dent J 1999;49:231-9.

18. Constantinescu IR, Ursache M, Mardarez D. Effect of pH on the surface roughness of heat cured denture base acrylic resins. Rev Med Chir Soc Med Nat Iasi 2007;111:477-81.

19. Verran J, Maryan CJ. Retention of Candida albicans on acrylic resin and silicone of different surface topography. J Prosthet Dent 1997;77:535-9.

20. Bollen CM, Lambrechts P, Quirynen M. Comparison of surface roughness of oral hard materials to the threshold surface roughness for bacterial plaque retention: A review of the literature. Dent Mater 1997;13:258-69.

21. Kuhar M, Funduk N. Effects of polishing techniques on the surface roughness of acrylic denture base resins. J Prosthet Dent 2005;93:76-85.

22. Tuncer D, Karaman E, Firat E. Does the temperature of beverages affect the surface roughness, hardness, and color stability of a composite resin? Eur J Dent 2013;7:165-71.

23. de Alencar E Silva Leite ML, da Cunha Medeiros E Silva FD, Meireles SS, Duarte RM, Andrade AK. The effect of drinks on color stability and surface roughness of nanocomposites. Eur J Dent 2014;8:330-6.

24. Gadelmawla ES, Koura MM, Maksoud TM, Elewa IM, Soliman HH Roughness parameters. J Mater Process Technol 2002;123:133-45.

25. Zhao K, Cheng XR, Chao YL, Li ZA, Han GL. Laboratory evaluation of a new denture adhesive. Dent Mater 2004;20:419-24.

26. Koda T, Tsuchiya H, Yamauchi M, Ohtani S, Takagi N, Kawano J. Leachability of denture-base acrylic resins in artificial saliva. Dent Mater 1990;6:13-6.

27. Jaeggi T, Grüninger A, Lussi A. Restorative therapy of erosion. Monogr Oral Sci 2006;20:200-14.

28. Miranda Dde A, Bertoldo CE, Aguiar FH, Lima DA, Lovadino JR. Effects of mouthwashes on Knoop hardness and surface roughness of dental composites after different immersion times. Braz Oral Res 2011;25:168-73

29. Ferracane JL. Hygroscopic and hydrolytic effects in dental polymer networks. Dent Mater 2006;22:211-22.

30. Woodruff CW, Peck GE, Banker GS. Effect of environmental conditions and polymer ratio on water vapor transmission through free plasticized cellulose films. J Pharm Sci 1972;61:1956-9.

31. Uysal H, Altay OT, Alparslan N, Bilge A. Comparison of four different denture cushion adhesives - A subjective study. J Oral Rehabil 1998;25:209-13.

32. Adisman IK. The use of denture adhesives as an aid to denture treatment. J Prosthet Dent 1989;62:711-5. 